\title{
The etiologic role of human papillomavirus in penile cancers: a study in Vietnam
}

\author{
H T T Do ${ }^{1}$, C Koriyama*,1, N A Khan ${ }^{1}$, M Higashi ${ }^{2}$, T Kato ${ }^{1}$, N T Le ${ }^{3}$, S Matsushita ${ }^{4}$, T Kanekura ${ }^{4}$ and \\ S Akiba ${ }^{1}$
}

${ }^{1}$ Department of Epidemiology and Preventive Medicine, Kagoshima University Graduate School of Medical and Dental Sciences, 8-35-1 Sakuragaoka, Kagoshima 890-8544, Japan; ${ }^{2}$ Department of Human Pathology, Kagoshima University Graduate School of Medical and Dental Sciences, 8-35-1 Sakuragaoka, Kagoshima 890-8544, Japan; ${ }^{3}$ Department of Occupational Health, Hanoi Medical University, 1st Ton That Tung street, Hanoi, Vietnam and ${ }^{4}$ Department of Dermatology, Kagoshima University Graduate School of Medical and Dental Sciences, 8-35-1 Sakuragaoka, Kagoshima 890-8544, Japan

Background: We investigated the aetiologic role of human papillomavirus (HPV) in 120 penile squamous cell carcinomas (PSCCs) from Vietnam.

Methods: Human papillomavirus DNA was detected by PCR using SPF10 primers and a primer set targeting HPV-16 E6. The INNO-LiPA HPV genotyping kit was used to determine genotype. Human papillomavirus-16 viral load and physical status were determined by real-time PCR. P16 ${ }^{\text {INK4A }}$ protein expression was investigated by immunohistochemistry.

Results: Human papillomavirus DNA was detected in 27 of 120 (23\%) PSCCs. The most frequently detected genotype was HPV-16 (24 of 27 cases, 89\%). In 16 of 18 (89\%) HPV-16-positive cases, the HPV DNA was considered to be integrated into the host genome. The geometric mean of the HPV-16 viral load was 0.4 copies per cell. P16 INK4A overexpression was significantly related to PSCCs infected with high-risk HPV $(P=0.018)$ and HPV-16 copy numbers $(P<0.001)$.

Conclusion: Human papillomavirus-16 DNA integration and p16 INK4A overexpression in high-risk HPV detected PSCCs suggested an aetiologic role of high-risk HPV in the development of PSCCs.

Penile cancer development is a multi-factorial process involving poor genital hygiene, phimosis, human papillomavirus (HPV), chronic inflammatory and premalignant conditions, and smoking (Misra et al, 2004). According to a systematic review, human papillomavirus (HPV) DNA was detected in 48\%, on average, of penile squamous cell carcinomas (PSCCs) and the most frequent HPV-related histotype (66\%) was basaloid PSCC (Backes et al, 2009).

The integration of high-risk HPV genome into the host genome is suspected to be an important event for malignant transformation and cancer progression (Wentzensen et al, 2004; Williams et al, 2011). It usually disrupts the E2 gene, a suppressor of the E6/E7 promoter, leading to the overexpression of viral oncogenes E6 and E7. The high viral load, frequently observed in cervical cancer, is also a determinant of cancer development (Wu et al, 2006).

The overexpression of $\mathrm{p} 16^{\mathrm{INK} 4 \mathrm{~A}}$ is a useful biomarker for evaluating the aetiologic role of HPV because HPV-E7 disturbs the $\mathrm{p} 16^{\mathrm{INK} 4 \mathrm{~A}} /$ cyclin $\mathrm{D} / \mathrm{Rb}$ pathway, leading to the accumulation of p16 ${ }^{\mathrm{INK} 4 \mathrm{~A}}$ (Narisawa-Saito and Kiyono, 2007). In PSCC, however, the association between $\mathrm{p} 16^{\mathrm{INK} 4 \mathrm{~A}}$ overexpression and HPV presence is still unestablished (Ferreux et al, 2003; Poetsch et al, 2011; Stankiewicz et al, 2011a).

To understand the aetiologic role of HPV in the development of PSCCs, we examined the presence, genotype, viral load and physical status of high-risk HPV, and $16^{1 \mathrm{IK} 4 \mathrm{~A}}$ expression in PSCCs in Vietnam.

\section{MATERIALS AND METHODS}

Study subjects. One hundred twenty paraffin-embedded PSCC specimens diagnosed at the National Cancer Hospital (Hanoi, Vietnam) between 2005 and 2010 were examined. Seventeen 
cervical cancer specimens obtained at the same hospital during the same period were used as positive controls as HPV is a necessary cause of cervical cancers (zur Hausen, 2002). Histological subtypes were confirmed according to the World Health Organization histological classification of PSCCs (Cubilla et al, 2004). On the basis of TNM classification (Pizzocaro et al, 2010), clinical stage was divided into four stages by one of the authors (HD). This study was approved by the Institutional Review Board of Kagoshima University Graduate School of Medical and Dental Sciences.

Human papillomavirus detection and genotyping. Extracted DNAs from tissue specimens were checked for their qualities and the absence of PCR inhibitors by PCR for $\beta$-globin (Khan et al, 2008). Human papillomavirus DNA was detected by PCR using
SPF10-biotinylated primers and a HPV-16-E6-specific primer set (Khan et al, 2008). Human papillomavirus typing was performed using the INNO-LiPA HPV Genotyping Extra test (Innogenetics, Ghent, Belgium) (Kleter et al, 1999), which can identify 28 genotypes: HPV $-16,-18,-31,-33,-35,-39,-45,-51,-52,-56$, $-58,-59,-68,-73,-82,-26,-53,-66,-6,-11,-40,-43,-44,-54,-70$, $-69,-71$ and -74 .

Quantitative real-time PCR. To examine the viral load and the physical status of HPV-16, all HPV-16-positive samples were subjected to quantitative real-time PCR with the ABI Prism 7700 Sequence Detection System (Applied Biosystems, Foster City, CA, USA) and 2x QuantiTect SYBR Green PCR kit (Qiagen, Hilden, Germany). Details of the procedure were reported in the previous

Table 1. Frequencies of HPV-positive cases by clinicopathological characteristics

\begin{tabular}{|c|c|c|c|c|}
\hline Clinicopathological characteristics & All $\mathbf{N}(\%)$ & HPV-negative $\mathbf{N}(\%)$ & HPV-positive $\mathbf{N}(\%)$ & $\boldsymbol{P}$-value ${ }^{a}$ \\
\hline Number of cases & 120 (100) & $93(77)$ & $27(23)$ & \\
\hline Mean age at diagnosis $(95 \% \mathrm{Cl})$ & $53(51,57)$ & $54(51,57)$ & $51(47,55)$ & $0.277^{\mathbf{b}}$ \\
\hline \multicolumn{5}{|l|}{ Age at diagnosis (years) } \\
\hline $\begin{array}{l}\leqslant 45 \\
46-55 \\
56-65 \\
66 \text { and above }\end{array}$ & $\begin{array}{l}32 \\
47 \\
17 \\
24\end{array}$ & $\begin{array}{l}24(75) \\
35(74) \\
12(71) \\
22(92)\end{array}$ & $\begin{array}{r}8(25) \\
12(26) \\
5(29) \\
2(8)\end{array}$ & 0.273 \\
\hline Histological subtype & & & & 0.354 \\
\hline $\begin{array}{l}\text { Basaloid } \\
\text { Keratinising (usual typec } \\
\text { Non-keratinising } \\
\text { Verrucous } \\
\text { Warty(condylomatous) } \\
\text { Undetermined }\end{array}$ & $\begin{array}{c}3 \\
83 \\
20 \\
8 \\
2 \\
4\end{array}$ & $\begin{aligned} & 1(33) \\
& 64(77) \\
& 17(85) \\
& 6(75) \\
& 2(100) \\
& 3(75)\end{aligned}$ & $\begin{aligned} 2 & (67) \\
19 & (23) \\
3 & (15) \\
2 & (25) \\
0 & (0) \\
1 & (25)\end{aligned}$ & \\
\hline Histological grade & & & & 0.104 \\
\hline $\begin{array}{l}1 \\
2 \\
3 \\
\text { Undetermined }^{\mathbf{d}}\end{array}$ & $\begin{array}{c}61 \\
36 \\
19 \\
4\end{array}$ & $\begin{array}{r}52(85) \\
25(70) \\
13(68) \\
3(75)\end{array}$ & $\begin{array}{r}9(15) \\
11(30) \\
6(32) \\
1(25)\end{array}$ & $P$ for trend $=0.120^{e}$ \\
\hline Stage & & & & 0.550 \\
\hline $\begin{array}{l}1 \\
2 \\
3 \\
4 \\
\text { Unknown }\end{array}$ & $\begin{array}{c}1 \\
29 \\
23 \\
6 \\
61\end{array}$ & $\begin{aligned} 1 & (100) \\
22 & (76) \\
16 & (70) \\
6 & (100) \\
48 & (79)\end{aligned}$ & $\begin{aligned} & 0(0) \\
7 & (24) \\
7 & (30) \\
0 & (0) \\
13 & (21)\end{aligned}$ & $P$ for trend $=0.815^{e}$ \\
\hline Phimosis history & & & & 0.433 \\
\hline $\begin{array}{l}\text { No } \\
\text { Yes } \\
\text { Unknown }\end{array}$ & $\begin{array}{l}11 \\
54 \\
55\end{array}$ & $\begin{array}{l}10(91) \\
40(74) \\
43(78)\end{array}$ & $\begin{array}{c}1(9) \\
14(26) \\
12(22)\end{array}$ & \\
\hline Anatomic localisation & & & & 0.180 \\
\hline $\begin{array}{l}\text { Penile glans } \\
\text { Penile preputium } \\
\text { Both glans and preputium } \\
\text { Unspecified/unknown }\end{array}$ & $\begin{array}{c}59 \\
3 \\
4 \\
54\end{array}$ & $\begin{aligned} 46(78) \\
1(33) \\
3(75) \\
43(80)\end{aligned}$ & $\begin{aligned} 13(22) \\
2(67) \\
1(25) \\
11(20)\end{aligned}$ & \\
\hline Smoking history & & & & 1.00 \\
\hline $\begin{array}{l}\text { No } \\
\text { Yes } \\
\text { Unknown }\end{array}$ & $\begin{array}{l}44 \\
12 \\
64 \\
\end{array}$ & $\begin{array}{l}35(80) \\
10(83) \\
48(75) \\
\end{array}$ & $\begin{array}{r}9(20) \\
2(17) \\
16(25) \\
\end{array}$ & \\
\hline 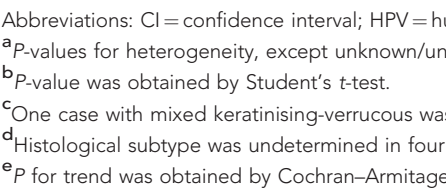 & $\begin{array}{l}\text { virus. } \\
\text { es, were obtair } \\
\text { ssue shortage. }\end{array}$ & exact test. & & \\
\hline
\end{tabular}


study (Khan et al, 2008). The physical status of the HPV-16 was determined by the HPV-16 E2/E6 ratio (Peitsaro et al, 2002). A lack of E2 amplification $(\mathrm{E} 2 / \mathrm{E} 6$ ratio $=0)$ represents HPV-16 DNA integration into the host genome. When the E2/E6 ratio was equal to or higher than unity (E2/E6 ratio $\geqslant 1$ ), the HPV-16 genome was considered as an episomal form, and the rest $(0<\mathrm{E} 2 / \mathrm{E} 6$ ratio $<1)$ was considered as a mixed form (mixture of episomal and integrated forms).

Immunohistochemistry for $\mathbf{p} 16^{\mathrm{INK}}{ }^{\mathrm{AA}}$. The immunohistochemistry was conducted, using the mouse monoclonal antibody against p16 ${ }^{\text {INK4A }}$ (1:150 dilutions, 551153, BD Pharmingen, Tokyo, Japan). Details of the procedure were reported in the previous study (Baba et al, 2010). The p16 $6^{\mathrm{INK} 4 \mathrm{~A}}$ expression was classified into the following four groups: $<10 \%, 10-49 \%, 50-89 \%$ and $\geqslant 90 \%$. The cases with $\geqslant 10 \%$ carcinoma cells stained positively were classified as positive.

\section{RESULTS}

The $\beta$-globin was detected in all samples, indicating that DNA was available for molecular analysis. Twenty-seven of 120 (23\%) PSCCs, including two of three (67\%) basaloid PSCCs, were HPV positive (Table 1). Twenty-three HPV-positive cases were detected by SPF10 primers, and additional four cases by a HPV-16-specific primer set (PC-1, PC-4, PC-7 and PC-8 in Supplementary Table 1). The HPV prevalence did not differ by any clinicopathological parameters. In cervical carcinomas, HPV DNA was detected in 94\% (16 out of 17) cases.

Human papillomavirus-16 was detected in 24 of 27 PSCCs. Other HPV genotypes detected included HPV-18, -11, -33 and -58 in one case each. Two cases had multiple infections: HPV-16/-58 and HPV-16/-18 (Supplementary Table 1).

Human papillomavirus-16 E6 DNA was quantified in 18 of 24 HPV-16-positive PSCCs (Supplementary Table 1). The geometric means of E6 copies per cell were 0.4 in PSCCs and 3.0 in cervical cancers. Human papillomavirus DNA was in the integrated form in seven $(39 \%)$, the mixed form in nine $(50 \%)$ and the episomal form in two (11\%) cases. In $13 \mathrm{HPV}$-16-positive cervical cancers, HPV integrated, mixed and episomal forms were found in four (31\%), three $(23 \%)$ and six (46\%) cases, respectively.

Eighteen of 25 high-risk HPV (16 HPV-16, one HPV-16/-58 and one HPV-33)-positive cases and 26 randomly selected HPVnegative PSCCs were subjected to immunohistochemistry. Seven high-risk HPV-positive cases (PC-4, PC-5, PC-11, PC-14, PC-16, $\mathrm{PC}-17$ and $\mathrm{PC}-22)$ were not examined due to tissue shortage.

Although $\mathrm{p} 16^{\mathrm{INK} 4 \mathrm{~A}}$ had both nuclear and cytoplasmic immunoreactivity (Figure $1 \mathrm{~A}$ and $\mathrm{D}$ ), samples showing cytoplasmic immunoreactivity alone (Figure $1 \mathrm{~B}$ and $\mathrm{E}$ ) were not regarded as positive because the functionally activated $\mathrm{p} 16^{\mathrm{INK} 4 \mathrm{~A}}$ was translocated into the nucleus. P16 ${ }^{\text {INK4A }}$ was expressed in 10 of 44 (23\%) PSCCs (Supplementary Table 2). Human papillomavirus-positive PSCCs tended to show a frequent $\mathrm{p} 16^{\mathrm{INK} 4 \mathrm{~A}}$ nuclear expression (Supplementary Table 2, $P=0.018$ ). Strong $\mathrm{p} 16^{\mathrm{INK} 4 \mathrm{~A}}$ nuclear expression was more frequently observed in HPV-16-positive PSCCs with a viral load $\geqslant 1$ than those with a viral load $<1$ and HPV-negative PSCCs (Table 2, $P$ for trend $<0.001$ ). Although all basaloid and non-keratinising types had high viral loads, $83 \%$ of the keratinising type harboured low viral loads (Table 2, $P=0.032)$. P16 ${ }^{\mathrm{NK} 4 \mathrm{~A}}$ expression was not related to other factors, including tumour grade or stage (Supplementary Table 2).

\section{DISCUSSION}

In the present study, $\mathrm{p} 16^{\mathrm{INK} 4 \mathrm{~A}}$ overexpression was frequently observed in high-risk HPV-positive PSCCs, which is consistent with the findings in cervical cancers (Hwang and Shroyer 2012) and some studies of PSCCs (Ferreux et al, 2003; Stankiewicz et al, 2011a). Regarding HPV-negative PSCCs, p16 ${ }^{\mathrm{INK} 4 \mathrm{~A}}$ expression was frequently suppressed by $\mathrm{p} 16^{\mathrm{INK} 4 \mathrm{~A}}$ gene mutation or promoter hypermethylation (Poetsch et al, 2011). However, three HPVnegative PSCCs also showed p16 $6^{\mathrm{INK} 4 \mathrm{~A}}$ overexpression (Table 2), which might occur independently of HPV infection such as mutational inactivation of pRB (Marur et al, 2010). A high viral load of HPV-16 was also related to strong $16^{\text {INK4A }}$ nuclear
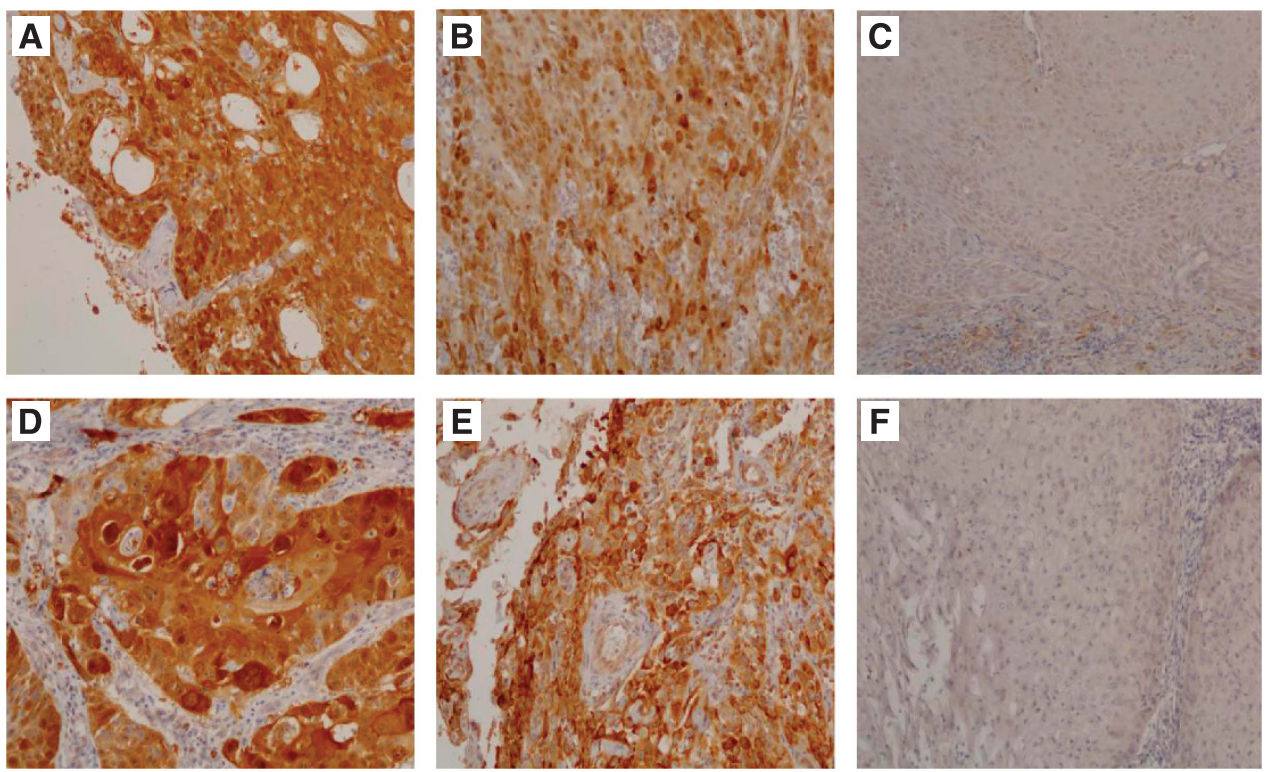

Figure 1. Representative examples of $\mathrm{p} 16^{\mathrm{INK} 4 \mathrm{~A}}$ immunostaining in PSCCs. (A) HPV positive, p16 INK4A both nuclear and cytoplasmic positive; (B) HPV positive, p16 INK4A cytoplasmic positive only; (C) HPV positive, p16 INK4A both nuclear and cytoplasmic negative; (D) HPV negative, p16

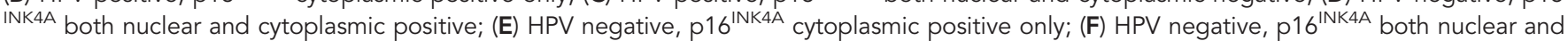
cytoplasmic negative. 
Table 2. Association of HPV-16 viral load with histological subtype and p16 ${ }^{\text {INK4A }}$ expression

\begin{tabular}{|c|c|c|c|c|}
\hline \multirow[b]{2}{*}{ Clinicopathological characteristics } & \multicolumn{4}{|c|}{ HPV-16 E6 viral load (per cell) } \\
\hline & HPV negative & Low $(<1) \mathbf{N}(\%)$ & High $(\geqslant 1) \mathbf{N}(\%)$ & $\boldsymbol{P}$-value ${ }^{a}$ \\
\hline Histological subtype & & & & 0.032 \\
\hline $\begin{array}{l}\text { Basaloid } \\
\text { Keratinising (usual type) } \\
\text { Non-keratinising } \\
\text { Verrucous } \\
\text { Warty(condylomatous) } \\
\text { Undetermined } \\
\text { Total }\end{array}$ & $\begin{array}{c}1(1) \\
64(69) \\
17(18) \\
6(6) \\
2(2) \\
3(3) \\
93(100)\end{array}$ & $\begin{array}{c}0(0) \\
10(83) \\
0(0) \\
1(8) \\
0(0) \\
1(8) \\
12(100)\end{array}$ & $\begin{array}{l}2(33) \\
2(33) \\
2(33) \\
0(0) \\
0(0) \\
0(0) \\
6(100)\end{array}$ & \\
\hline p16 $6^{\text {INK4A }}$ expression level & & & & 0.001 \\
\hline $\begin{array}{l}<10 \% \\
10-49 \% \\
50-89 \% \\
\geqslant 90 \% \\
\text { Total }\end{array}$ & $\begin{array}{c}23(88) \\
3(12) \\
0(0) \\
0(0) \\
26^{c}(100)\end{array}$ & $\begin{array}{l}8(89) \\
1(11) \\
0(0) \\
0(0) \\
9(100) \\
\end{array}$ & $\begin{array}{l}0(0) \\
0(0) \\
3(100) \\
0(0) \\
3(100) \\
\end{array}$ & $P$ for trend $<0.001^{b}$ \\
\hline \multicolumn{5}{|c|}{$\begin{array}{l}\text { Abbreviation: HPV = human papillomavirus. } \\
a_{P \text {-values for heterogeneity, except unknown/undetermined cases, were obtained by Fisher's exact test. }} \\
b_{P} \text { for trend was obtained by linear-by-linear association test. } \\
c_{26} \text { HPV-negative samples were randomly selected from all HPV-negative samples. }\end{array}$} \\
\hline
\end{tabular}

expression and almost none of the cases with viral load $<1$ copy per cell showed $\mathrm{p} 16^{\mathrm{INK} 4 \mathrm{~A}}$ overexpression. To our knowledge, this is the first study reporting this association. P16 ${ }^{\mathrm{INK} 4 \mathrm{~A}}$ overexpression may predict HPV transcription activity as reported in tonsillar cancer (Hoffmann et al, 2010).

The median HPV-16 viral loads (ranges) were 60.1255 $(10.7-1239)$ and $0.0355(0.002-0.322)$ copies per cell in the high $(\geqslant 1$ per cell) and low $(<1$ per cell) viral load groups, respectively. These ranges were similar to those in HPV-16 E6 mRNA-positive and -negative PSCCs, respectively (Heideman et al, 2007). Thus, approximately one copy per cell is a reasonable threshold to distinguish the viral transcription activity.

Relatively low viral loads in PSCCs might be due to the frequent HPV-16 integration because the viral load decreases after viral integration into the host genome (Berumen et al, 1995). The high frequency (89\%) of HPV-16 integration in Vietnamese PSCCs (both integrated and mixed forms) is consistent with the findings by Tornesello et al (1997) and Kalantari et al (2008). Human papillomavirus integration, a marker of HPV-induced neoplasia, is not always found in cervical cancers (Cullen et al, 1991; Vernon et al, 1997). The discrepancy in HPV-16 integration rate between PSCCs and cervical cancers in the current study could be explained by the difference in tumour histological grades or aggressiveness, as HPV integration frequently occurs in a severe dysplastic lesion and invasive cervical carcinomas (Wentzensen et al, 2004). However, our sample size was too small to explore this hypothesis: only two PSCCs were in episomal form.

Demographic features and genetic backgrounds may contribute to the geographical difference of HPV prevalence in PSCCs worldwide. To date, there is no study reporting the HPV presence in PSCC in Vietnam. Although the HPV prevalence in Vietnamese PSCCs was relatively lower than the world average, a high frequency (94\%) of HPV in cervical cancers indicated the appropriateness of our HPV DNA detection procedure.

Human papillomavirus presence was not significantly related to other PSCC risk factors including phimosis and smoking. Although clinical information was not obtained from nearly half of the study subjects, the HPV prevalence in these cases (20-25\%) differed little from that of the entire group (23\%). Thus, our negative finding was unlikely caused by biased information.

\section{CONCLUSION}

The aetiologic role of high-risk HPV in the development of PSCCs was suggested by its DNA integration into the PSCC genome and its association with $\mathrm{p} 16^{\mathrm{INK} 4 \mathrm{~A}}$ overexpression. $\mathrm{P} 16^{\mathrm{INK} 4 \AA}$ could be a biomarker for HPV-related PSCCs.

\section{ACKNOWLEDGEMENTS}

This work was supported by Grants-in-Aids for Scientific Research on Priority Areas (17015037) of the Ministry of Education, Culture, Sports, Science and Technology, Japan. We would like to express our gratefulness to Dr Ta Van To, Department of Cytology and Pathology, National Cancer Hospital, 43 Quan Su, Hanoi, Vietnam, for kindly giving paraffin block specimens. We thank Joint Research Laboratory, Kagoshima University Graduate School of Medical and Dental Sciences, for the use of their facilities. We also thank Ms Junko Habu for her technical assistance.

\section{REFERENCES}

Baba M, Castillo A, Koriyama C, Yanagi M, Matsumoto H, Natsugoe S, Shuyama KY, Khan N, Higashi M, Itoh T, Eizuru Y, Aikou T, Akiba S (2010) Human papillomavirus is frequently detected in gefitinibresponsive lung adenocarcinomas. Oncol Rep 23(4): 1085-1092.

Backes DM, Kurman RJ, Pimenta JM, Smith JS (2009) Systematic review of human papillomavirus prevalence in invasive penile cancer. Cancer Causes Control 20: 449-457.

Berumen J, Unger ER, Casas L, Figueroa P (1995) Amplification of human papillomavirus types 16 and 18 in invasive cervical cancer. Hum Pathol 26: 676-681.

Cubilla AL, Dillner J, Schellhammer PF, Horenblas S (2004) Tumours of the penis: malignant epithelial tumours. In Eble JN, Sauter G, Epstein JI, Sesterhenn I (eds) Chap 5. World Health Organization Classification of Tumours Pathology \& Genetics of Tumours of the Urinary System and Male Genital Organs. pp 281-290. IARC: Lyon. 
Cullen AP, Reid R, Campion M, Lörincz AT (1991) Analysis of the physical state of different human papillomavirus DNAs in intraepithelial and invasive cervical neoplasm. J Virol 65: 606-612.

Ferreux E, Lont AP, Horenblas S, Gallee MP, Raaphorst FM, von Knebel Doeberitz M, Meijer CJ, Snijders PJ (2003) Evidence for at least three alternative mechanisms targeting the $\mathrm{p} 16 \mathrm{INK} 4 \mathrm{~A} / \mathrm{cyclinD} / \mathrm{Rb}$ pathway in penile carcinoma, one of which is mediated by high-risk human papillomavirus. J Pathol 201: 109-118.

Heideman DA, Waterboer T, Pawlita M, Delis-van Diemen P, Nindl I, Leijte JA, Bonfrer JM, Horenblas S, Meijer CJ, Snijders PJ (2007) Human papillomavirus-16 is the predominant type etiologically involved in penile squamous cell carcinoma. J Clin Oncol 25: 4550-4556.

Hoffmann M, Ihloff AS, Görögh T, Weise JB, Fazel A, Krams M, Rittgen W, Schwarz E, Kahn T (2010) P16(INK4a) overexpression predicts translational active human papillomavirus infection in tonsillar cancer. Int J Cancer 127: 1595-1602.

Hwang SJ, Shroyer KR (2012) Biomarkers of cervical dysplasia and carcinoma. J Oncol 2012: doi:10.1155/2012/507286.

Kalantari M, Villa LL, Calleja-Macias IE, Bernard HU (2008) Human papillomavirus-16 and -18 in penile carcinomas: DNA methylation, chromosomal recombination and genomic variation. Int J Cancer 123: 1832-1840.

Khan NA, Castillo A, Koriyama C, Kijima Y, Umekita Y, Ohi Y, Higashi M, Sagara Y, Yoshinaka H, Tsuji T, Natsugoe S, Douchi T, Eizuru Y, Akiba S (2008) Human papillomavirus detected in female breast carcinomas in Japan. Br J Cancer 99: 408-414.

Kleter B, Van Doorn LJ, Schrauwen L, Molijin A, Sastrowijoto S, ter Schegget J, Lindeman J, terHarmsel B, Burger M, Quint W (1999) Development and clinical evaluation of a highly sensitive PCR-reverse hybridization line probe assay for detection and identification of anogenital human papillomavirus. J Clin Microbiol 37: 2508-2517.

Marur S, D'Souza G, Westra WH, Forastiere AA (2010) HPV-associated head and neck cancer: a virus-related cancer epidemic. Lancet Oncol 11(8): 781-789.

Misra S, Chaturvedi A, Misra NC (2004) Penile carcinoma: a challenge for the developing world. Lancet Oncol 5: 240-247.

Narisawa-Saito M, Kiyono T (2007) Basic mechanisms of high-risk human papillomavirus-induced carcinogenesis: roles of E6 and E7 proteins. Cancer Sci 98: 1505-1511.
Peitsaro P, Johansson B, Syrjanen S (2002) Integrated human papillomavirus type 16 is frequently found in cervical cancer precursors as demonstrated by a novel quantitative real-time PCR technique. J Clin Microbiol 40: 886-891.

Pizzocaro G, Algaba F, Horenblas S, Solsona E, Tana S, Van Der Poel H, Watkin NA (2010) EAU Penile cancer guidelines 2009. Eur Urol 57: 1002-1012.

Poetsch M, Hemmerich M, Kakies C, Kleist B, Wolf E, vom Dorp F, Hakenberg OW, Protzel C (2011) Alterations in the tumor suppressor gene p16(INK4A) are associated with aggressive behavior of penile carcinomas. Virchows Arch 458(2): 221-229.

Stankiewicz E, Prowse DM, Ktori E, Cuzick J, Ambroisine L, Zhang X, Kudahetti S, Watkin N, Corbishley C, Berney DM (2011a) The retinoblastoma protein/p16 INK4A pathway but not p53 is disrupted by human papillomavirus in penile squamous cell carcinoma. Histopathology 58: $433-439$.

Tornesello ML, Buonaguro FM, Meglio A, Buonaguro L, Beth-Giraldo E, Giraldo G (1997) Sequence variations and viral genomic state of human papillomavirus type 16 in penile carcinomas from Ugandan patients. $J$ Gen Virol 78: 2199-2208.

Vernon SD, Unger ER, Miller DL, Lee DR, Reeves WC (1997) Association of human papillomavirus type 16 integration in the E2 gene with poor disease-free survival from cervical cancer. Int J Cancer 74: 50-56.

Wentzensen N, Vinokurova S, von Knebel Doeberitz M (2004) Systematic review of genomic integration sites of human papillomavirus genomes in epithelial dysplasia and invasive cancer of the female lower genital tract. Cancer Res 64(11): 3878-3884.

Williams VM, Filippova M, Soto U, Duerksen-Hughes PJ (2011) HPV-DNA integration and carcinogenesis: putative roles for inflammation and oxidative stress. Future Virol 6: 45-57.

Wu Y, Chen Y, Li L, Yu G, Zhang Y, He Y (2006) Associations of high-risk HPV types and viral load with cervical cancer in China. J Clin Virol 35: 264-269.

zur Hausen H (2002) Papillomaviruses and cancer: from basic studies to clinical application. Nat Rev Cancer 2: 342-350.

This work is published under the standard license to publish agreement. After 12 months the work will become freely available and the license terms will switch to a Creative Commons AttributionNonCommercial-Share Alike 3.0 Unported License.

Supplementary Information accompanies this paper on British Journal of Cancer website (http://www.nature.com/bjc) 